\title{
BREAKFAST AND HEMOGLOBIN LEVEL AMONG FEMALE JUNIOR HIGH SCHOOL STUDENT IN SURAKARTA, CENTRAL JAVA
}

\author{
Ropitasari'), Fanny Kartika ${ }^{2}$ ), Rachmi Fauziah $\mathbf{R}^{3}$ ) \\ Sri Anggarini 1) \\ 1) Diploma III of Midwifery, Universitas Sebelas Maret \\ 2) Postgraduate Program, Universitas Sebelas Maret \\ 3) Radiology Section of Dr Moewardi Hospital, Surakarta
}

\begin{abstract}
Background: Physical activity among school-age adolescents make them skipping the breakfast. Skipping breakfast can cause a loss of energy and nutrients needed for hemoglobin $(\mathrm{Hb})$ synthesis. This study aimed to examine the effect of breakfast on anemia levels among female adolescent.

Subjects and Method: A cross-sectional was conducted by involving 30 female adolescent aged 13-15. The study subjects were divided into 30 female adolescent had breakfast group and 30 female adolescent had no breakfast group. Breakfast was the consumption of food and side dishes from waking up until 10:00 AM. The dependent variable was $\mathrm{Hb}$ level and the dependent variable was breakfast. The data were collected by measuring the HB level and questionnaire. The data then analyzed using Chi-square test. The association between breakfast habits and hemoglobin levels was analyzed by means of the Gamma Somers test.

Results: The breakfast habit increased the $\mathrm{Hb}$ level among female adolescent $(\mathrm{OR}=1.75$; $\mathrm{p}=0.003$ ), and it was statistically significant.

Conclusion: Female adolescent with a good breakfast habit increase the $\mathrm{Hb}$ level and prevent the anemia.
\end{abstract}

Keywords: breakfast, female adolescent, hemoglobin levels

Correspondence:

Ropitasari. Diploma III of Midwifery, Universitas Sebelas Maret, Surakarta. Jl. Ir. Sutami 36A, Surakarta 57126, Central Java, Indonesia.Email: ropita.uns@gmail.com. Mobile: o8222023585

The $7^{\text {th }}$ International Conference on Public Health

Solo, Indonesia, November 18-19, 2020 | 162

https://doi.org/10.26911/the7thicph.02.52 